WSRC-RP-98-01143

\title{
RESULTS OF SCOPING STUDIES FOR DETERMINING RADIOLYTIC HYDROGEN PRODUCTION FROM : MOIST CST AND CST SLURRIES
}

\author{
N. E. Bibler, C. L. Crawford, and C. R. Biddle \\ Westinghouse Savannah River Company \\ Savannah River Technology Center
}

October 2, 1998

Westinghouse Savannah River Company

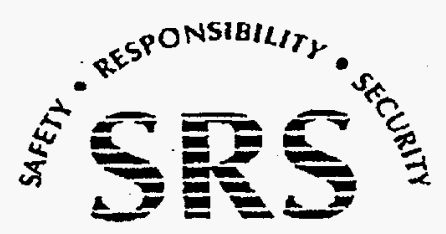

SAVANNAH RIVER SITE

PREPARED FOR THĖ U.S. DEPARTMENT OF ENERGY UNDER CONTRACT NO. DE-AC09-96SR18500 


\section{DISCLAIMER}

This report was prepared as an account of work sponsored by an agency of the United States Government. Neither the United States Government nor any agency thereof, nor any of their employees, makes any warranty, express or implied, or assumes any legal liability or responsibility for the accuracy, completeness, or usefulness of any information, apparatus, product, or process disclosed, or represents that its use would not infringe privately owned rights. Reference herein to any specific commercial product, process, or service by trade name, trademark, manufacturer, or otherwise does not necessarily constitute or imply its endorsement, recommendation, or favoring by the United States Government or any agency thereof. The views and opinions of authors expressed herein do not necessarily state or reflect those of the United States Government or any agency thereof.

This report has been reproduced directly from the best available copy.

Available to DOE and DOE contractors from the Office of Scientific and Technical Information, P.O. Box 62, Oak Ridge, TN 37831; prices available from (615) 576-8401.

Available to the public from the National Technical Information Service, U.S. Department of Commerce, 5285 Port Royal Road, Springfield, VA 22161. 


\section{DISCLAIMER}

Portions of this document may be illegible in electronic image products. Images are produced from the best available original document. 
Savannah River Technology Center Immobilization Technology Section
WSCR-RP-98-01143

Page 2 of 15

Approvals

!

Eusbetigefuter

E. W. Holtzscheiter

$10-5-98$

Date
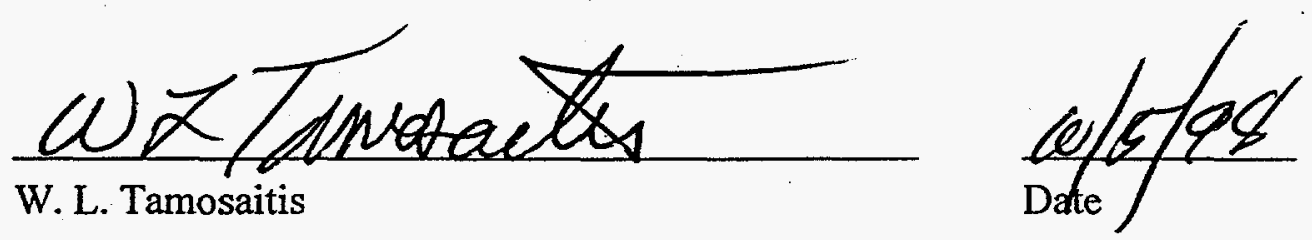

W. L. Tamosaitis

Technical Review

Tom R Harbour

$\frac{10 / 5 / 98}{\text { Date }}$ 


\section{INTRODUCTION AND SUMMARY}

In support of the Salt Disposition team, scoping studies have been performed on the radiolysis of moist and aqueous slurries of Crystalline Silicotitanate(CST). If CST is used for removal of Cs-137 from SRS salt solutions, radiolysis of the water by Cs-137 on the CST will produce $\mathrm{H}_{2}$. Also it has been shown that the presence of a solid in the system can enhance the production of $\mathrm{H}_{2}$ by transferring absorbed energy from the solid to the water (1). As indicated in the test plan (2) for this scoping study, it is the intent of this study to determine if CST enhances the radiolytic production of $\mathrm{H}_{2}$ and to estimate the radiolytic hydrogen generation rate from an aqueous CST slurry in a column at the maximum expected Cs-137 loading on the CST.

Initially several CST slurry systems were irradiated with Co-60 gamma rays and the radiolytic yield of $\mathrm{H}_{2}$ measured in terms of its $\mathrm{G}$ value (molecules of $\mathrm{H}_{2}$ produced per $100 \mathrm{eV}$ of energy absorbed). Based on the results of these tests it was determined that CST did not enhance the radiolytic production of $\mathrm{H}_{2}$ by transferring energy to the water and causing it to decompose.

Calculations were then performed to estimate the rate of $\mathrm{H}_{2}$ production from a process column $16 \mathrm{ft}$. long by $5 \mathrm{ft}$. in diameter containing CST that was fully loaded with Cs-137. The maximum rate of $\mathrm{H}_{2}$ production based on the $\mathrm{G}$ values measured in this study was one liter per minute at STP $(0.04 \mathrm{cfm})$. This was for a $63 \%$ water/CST slurry with a $\mathrm{G}$ value of 0.2 molecules $/ 100 \mathrm{eV}$ for $\mathrm{H}_{2}$ production and a loading of 1 gram of Cs-137 per 100 grams of resin. The present work also indicates that for a column containing salt solution and CST rather than water and CST, the rate would be $4 \mathrm{X}$ lower. This lower value is much more realistic.

\section{EXPERIMENTAL METHODS}

\section{CST Samples and Systems Irradiated}

CST samples were obtained from Batch 4 of D. D. Walker of SRTC (3). The CST was in the form of small spherical beads of nominally 30-60 mesh size. About 100 grams of CST powder was exposed to ambient atmosphere in a shallow dish in order to equilibrate the CST to ambient atmospheric conditions prior to irradiation. This exposed CST was then used in all subsequent irradiations. The moisture content of the resulting CST powder was measured to be $13 \pm 1 \%$ by drying 4 gram triplicate samples at $250^{\circ} \mathrm{C}$ for overnight. It has been shown that temperatures this high are necessary to completely dry the CST (4). This experimentally determined moisture content of $13 \%$ water is within the range of similar 
results reported by Walker(3). Walker measured moisture contents of various batches of CST to be 2.7 to $13.0 \mathrm{wt} \%$ water upon drying overnight at $100^{\circ} \mathrm{C}$.

Initially, duplicate samples of the moist CST were irradiated without addition of any liquid. Next, two CST-liquid slurry systems were irradiated. The liquid used in these tests was either deionized water or $1 \mathrm{M} \mathrm{NaOH}$. In these slurries, known amounts of dry CST were contacted with the liquid and allowed to stand for approximately 1 hour. After this contact period, excess liquid was decanted from the settled CST slurries and known amounts of the damp slurry were added to the irradiation vessels. The CST pretreatment step simulates a CST conditioning step with alkaline solution that might be used in actual processing. Known amounts of fresh solutions of either the deionized water or $1 \mathrm{M} \mathrm{NaOH}$ were then added to the damp CST in the radiation vessel to give the final CST-liquid slurries (37\% CST/63\% water or $1 \mathrm{M} \mathrm{NaOH}$ ). The systems were then sealed, leak tested, and irradiated. Two different slurries were used in a third irradiation. These slurries were a $61 \% \mathrm{CST} / 39 \%$ salt solution and $17 \% \mathrm{CST} / 83 \%$ deionized water. The salt solution contained $\mathrm{Na}^{+}, \mathrm{NO}_{3}^{-}, \mathrm{NO}_{2}^{-}$and $\mathrm{OH}^{-}$ions.

\section{Irradiation Methods}

Irradiations were carried out in a Co-60 gamma ray source submerged beneath $30 \mathrm{ft}$. of water for shielding purposes. The temperature of slurries during the irradiations was $\sim 35^{\circ} \mathrm{C}$ due to gamma heating. A diagram of the irradiation apparatus is shown in Figure 1. Two samples could be irradiated simultaneously. For each experiment, a known amount of CST or CST/liquid slurry was placed in a $45 \mathrm{ml}$ stainless steel vessel ( $1 \mathrm{in}$. diameter and $4.5 \mathrm{in}$. length). The vessel was connected via $4 \mathrm{ft}$. of $1 / 8 \mathrm{in.}$ O.D. stainless steel tubing and $24 \mathrm{ft}$. of $1 / 8$ inch O.D. nylon pressure tubing to a calibrated pressure transducer located outside of the radiation field. A gas sampling septum was located $\sim 4 \mathrm{ft}$. above the steel vessel at the stainless steel/nylon pressure tube interface. This gas sampling septum was used to calibrate the void volume of the apparatus before the irradiations. To determine the void volume in the free gas in the system, successive 5-cc additions of air were added to the sealed system and the pressure increases recorded. Using the ideal gas law and the pressure increases, the constant void volume of the apparatus could be calculated. After the apparatus was leak checked and its void volume determined, the apparatus was then resealed and was ready for irradiation. For irradiation, both vessels had to be placed in a larger stainless steel cylindrical vessel (4" diameter and 12" length) which was attached to cables used to lower them into the Co-60 source. The slurries were irradiated for typically 2-6 days. During this time, the gas pressure generated in each apparatus was recorded periodically throughout the irradiation time. 


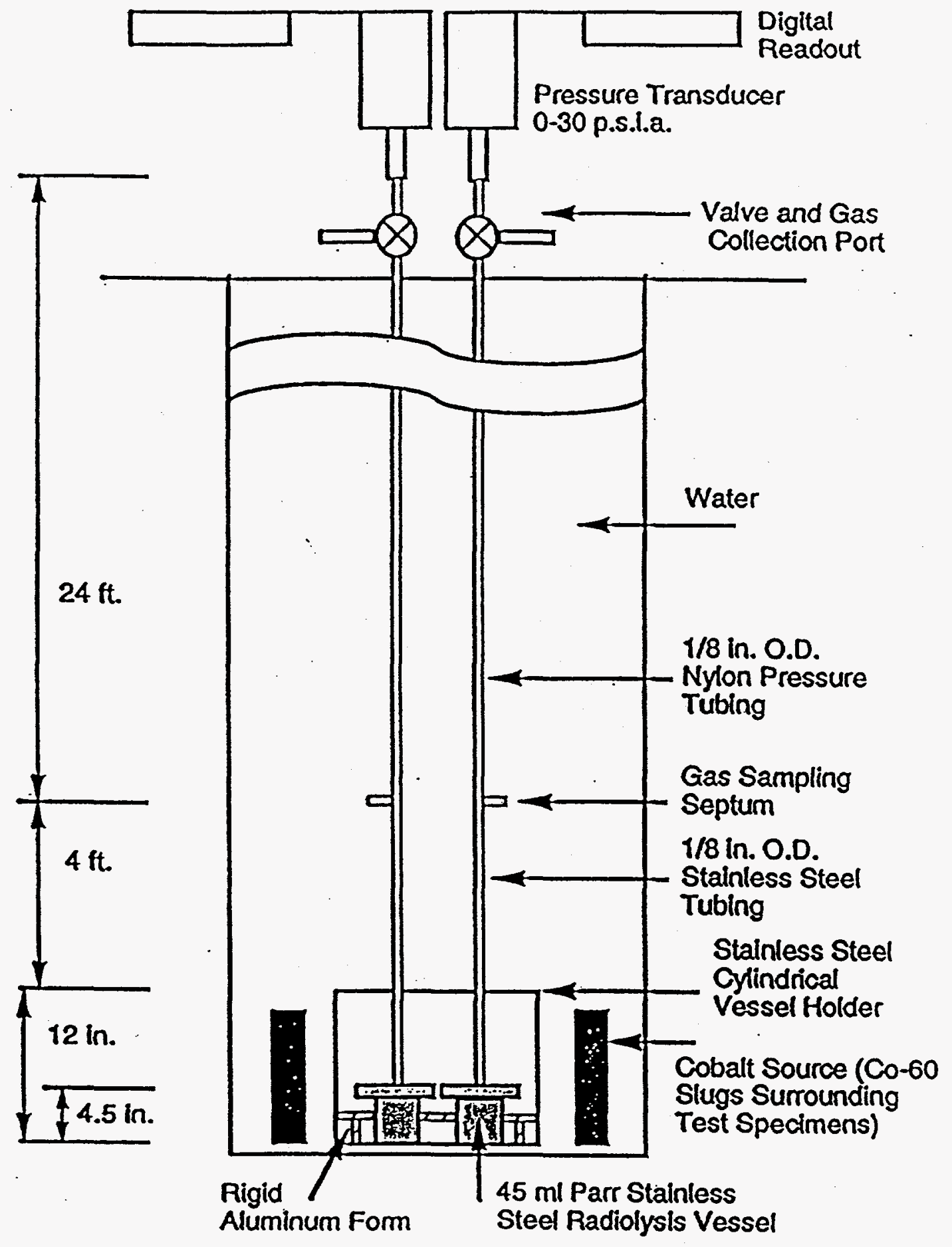

Figure 1. Diagram of Irradiation Apparatus Used to Measure Radiolytic Pressure Production. 


\section{Gas Analyses}

After the sample vessels were removed from the radiation field, a 1-L evacuated glass bulb was connected to the gas collection port valve of each apparatus. The $1-\mathrm{L}$ bulbs were evacuated with a standard mechanical pump by pulling a vacuum on them for a few minutes prior to use. The gas contained in the void volume of each apparatus was then expanded into each evacuated 1-L bulb by slowly opening the system needle-valve. The $1-\mathrm{L}$ bulbs were purposely made much larger than the $<100 \mathrm{cc}$ void volume in each apparatus to ensure that at least $95 \%$ of the total gas was removed from each irradiation apparatus. The 1-L glass bulb was then sealed and disconnected from the radiation vessel system. The $1-\mathrm{L}$ bulb was then brought up to atmospheric pressure by briefly opening the 1-L bulb to the atmosphere. This dilution of radiolytic gases with air was accounted for in subsequent gas component calculations using measured volumes of both the original sealed system and the total volume of the original sealed system plus 1-L bulb. The 1-L bulb was sealed after equilibration with atmosphere and transported to a gas chromatograph for gaseous analyses. Gases produced from irradiation of CST and CST slurries were analyzed by gas chromatography with a Varian Model 3400 gas chromatograph (thermal conductivity detector, chromosorb-101 and molecular sieve columns, argon carrier gas). Gases detected and analyzed for were $\mathrm{H}_{2}, \mathrm{O}_{2}, \mathrm{~N}_{2}$. Standard gases (Scott Specialty Gases, accuracy $=+/-2 \%$ ) containing these components in the range of $1-10$ vol\% were used for calibration. Moles of $\mathrm{H}_{2}$ produced were then calculated from the ideal gas law by knowing the measured $\mathrm{H}_{2}$ vol\% in air, the final system pressure just prior to removal from the radiation source, the total system void volume and a nominal temperature of $30^{\circ} \mathrm{C}$.

\section{Radiation Dosimetry}

The radiation dose rate of the Co-60 source was measured using a standard dosimetry method that was based on measuring gas production from radiolytic decomposition of water (5). The dosimeter solution is $0.0001 \mathrm{M}$ potassium iodide $(\mathrm{KI})$. The $\mathrm{KI}$ prevents the primary radiolytic products $\mathrm{H}_{2}$ and $\mathrm{H}_{2} \mathrm{O}_{2}$ from recombining in the radiation field. Figure 2 shows the pressures produced when two identical $0.0001 \mathrm{M}$ KI systems were irradiated in sealed vessels (In Figure 2, the lines are drawn by the computer software). After $\sim 2$ days irradiation, the systems were removed from the source and gas was analyzed.

Compositions of hydrogen gas and experimental details are given in Table 1. Table 1 shows the total dose rate calculated from moles of $\mathrm{H}_{2}$ produced and the reference $\mathrm{G}$ value for $\mathrm{H}_{2}$. The reference $\mathrm{G}\left(\mathrm{H}_{2}\right)$ value for $\mathrm{KI}$ dosimeter is 0.383 molecules/ $100 \mathrm{eV}$ (5). This dose rate is in excellent agreement with that measured earlier using the thin film dosimeters (6) after decaying the Co-60 radiation to the time of the current experiments. Table 1 data also shows the precision of measured dose rates $(\% \mathrm{RSD}<4 \%)$ from duplicate samples irradiated simultaneously is very good. 


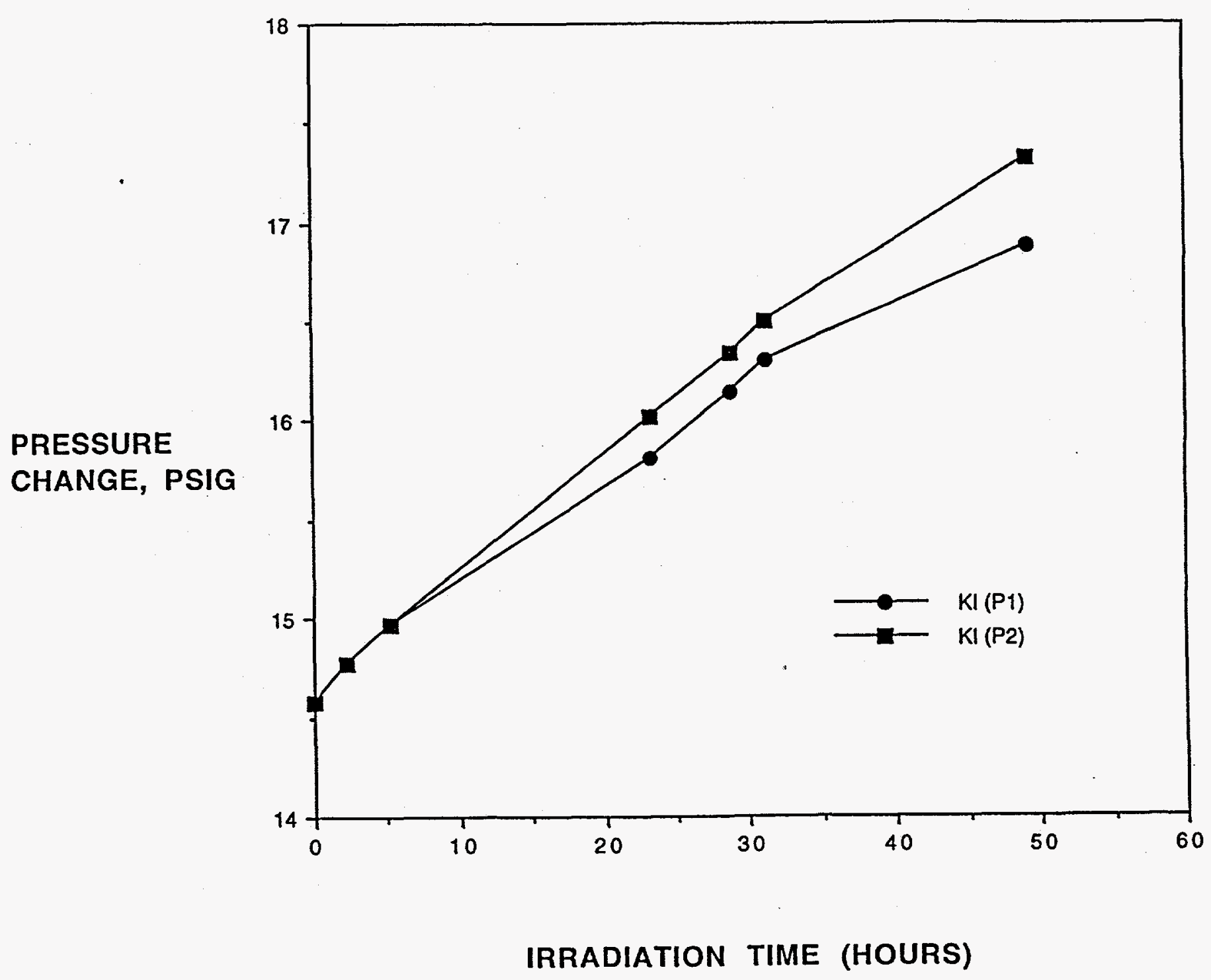

Figure 2. Pressures Produced from Radiolysis of Potassium Iodide Dosimetry System. 


\section{TABLE 1. FINAL HYDROGEN GAS COMPOSITION AND CALCULATED DOSE RATES FROM RADIOLYSIS OF 0.0001 M KI DOSIMETER SOLUTIONS}

$\begin{array}{lcc}\text { Experimental Details } & \text { Vessel 1 } & \text { Vessel 2 } \\ \text { Initial Pressure, PSIA } & 14.58 & 14.58 \\ \text { Final Pressure, } & 16.88 & 17.32 \\ \text { PSIA } & & \\ \text { Irradiation Time, h } & 49.25 & 49.25 \\ \text { Mass Solution, g } & 39.5 & 39.7 \\ & & \\ \text { Void Volume, cc } & 48.8 \pm 0.3 & 50.8 \pm 0.4\end{array}$

Final Gas Compositions

Vol\% Hydrogen
Vessel

12.7

\begin{abstract}
Vessel 2
\end{abstract}
12.0

12.4

St. Dev. \% R.S.D

0.5

4.0

$\begin{array}{lccccc}\text { Calculated Dose Rates } & \text { Vessel } 1 & \text { Vessel } 2 & \text { Average } & \text { St. Dev. } & \text { \% R.S.D } \\ \text { Dose Rate, } \mathrm{rad} / \mathrm{h} & 4.06 \mathrm{E}+05 & 4.25 \mathrm{E}+05 & 4.16 \mathrm{E}+05 & 0.14 \mathrm{E}+05 & 3.3\end{array}$

Methods for Calculating G Values

Radiolytic $\mathrm{G}$ values (molecules produced per $100 \mathrm{eV}$ absorbed) for hydrogen were calculated knowing the moles of $\mathrm{H}_{2}$ produced and the gamma ray energy absorbed by the system based on the dosimetry. Two different $\mathrm{G}$ values were calculated. One was based on the energy absorbed by the total mass of the CST slurry being irradiated. This includes both the CST and the water. The second was based on energy absorbed by only the mass of water present. If the CST enhances the radiolytic production of $\mathrm{H}_{2}$ from the water, the second $\mathrm{G}$ value should be greater than 0.45 molecules per $100 \mathrm{eV}$, the maximum $\mathrm{G}$ value for $\mathrm{H}_{2}$ production from pure water (7). 


\section{RESULTS AND DISCUSSION}

\section{RESULTS FROM IRRADIATION TESTS}

\section{Moist CST and CST/Water Slurries}

The purpose of these tests was to determine if the presence of CST in the slurries increased the G value for $\mathrm{H}_{2}$ production by transferring energy absorbed by the CST to cause water to decompose to give $\mathrm{H}_{2}$. These systems were as received CST that contained $13 \mathrm{wt} \%$ water, a slurry that was $63 \%$ water slurry and a slurry that was $83 \%$ water. The slurry that was $63 \%$ water was intended to simulate the slurry in a column of CST resin that could be used for Cs removal from SRS supernates. The $83 \%$ water slurry simulated a slurry that could be pumped or might be present in a storage tank. Calculated $\mathrm{G}$ values for $\mathrm{H}_{2}$ based on energy absorbed by the total slurry and on energy absorbed by the water are given in Table 2 and radiolytic pressure changes for these three systems are shown in Figure 3. (In Figure 3, the lines are drawn by the computer software.)

\section{TABLE 2. G VALUES FOR HYDROGEN PRODUCTION FROM RADIOLYSIS} OF MOIST CST AND CST-WATER SLURRIES

$$
\mathrm{G}\left(\mathrm{H}_{2}\right) \quad \mathrm{G}\left(\mathrm{H}_{2}\right)
$$

$\begin{array}{lcc}\frac{\text { System }}{\text { Moist CST }} & \frac{\text { Based on CST }+\mathrm{H}_{2} \mathrm{O}}{0.019 \pm 0.005} & \frac{\text { Based on Water }}{0.14 \pm 0.01} \\ \frac{\left(13 \% \mathrm{H}_{2} \mathrm{O}\right)}{\mathrm{CST}-\mathrm{H}_{2} \mathrm{O}} & 0.20 & 0.32 \\ \left.\frac{\left(63 \% \mathrm{H}_{2}\right.}{2}\right)^{\mathrm{a}, \mathrm{b}} & & \\ \mathrm{CST}-\mathrm{H}_{2} \mathrm{O} & 0.15 & 0.18 \\ \left(83 \% \mathrm{H}_{2} \mathrm{O}\right)^{\mathrm{a}, \mathrm{c}} & & \end{array}$

\footnotetext{
${ }^{a}$ Corrected for water in moist CST.

${ }^{b}$ Calculated percent water in a processing column of CST.

${ }^{-c}$ Calculated percent water in CST slurry that can be pumped.
} 


\section{PRESSURE CHANGE, PSIG}

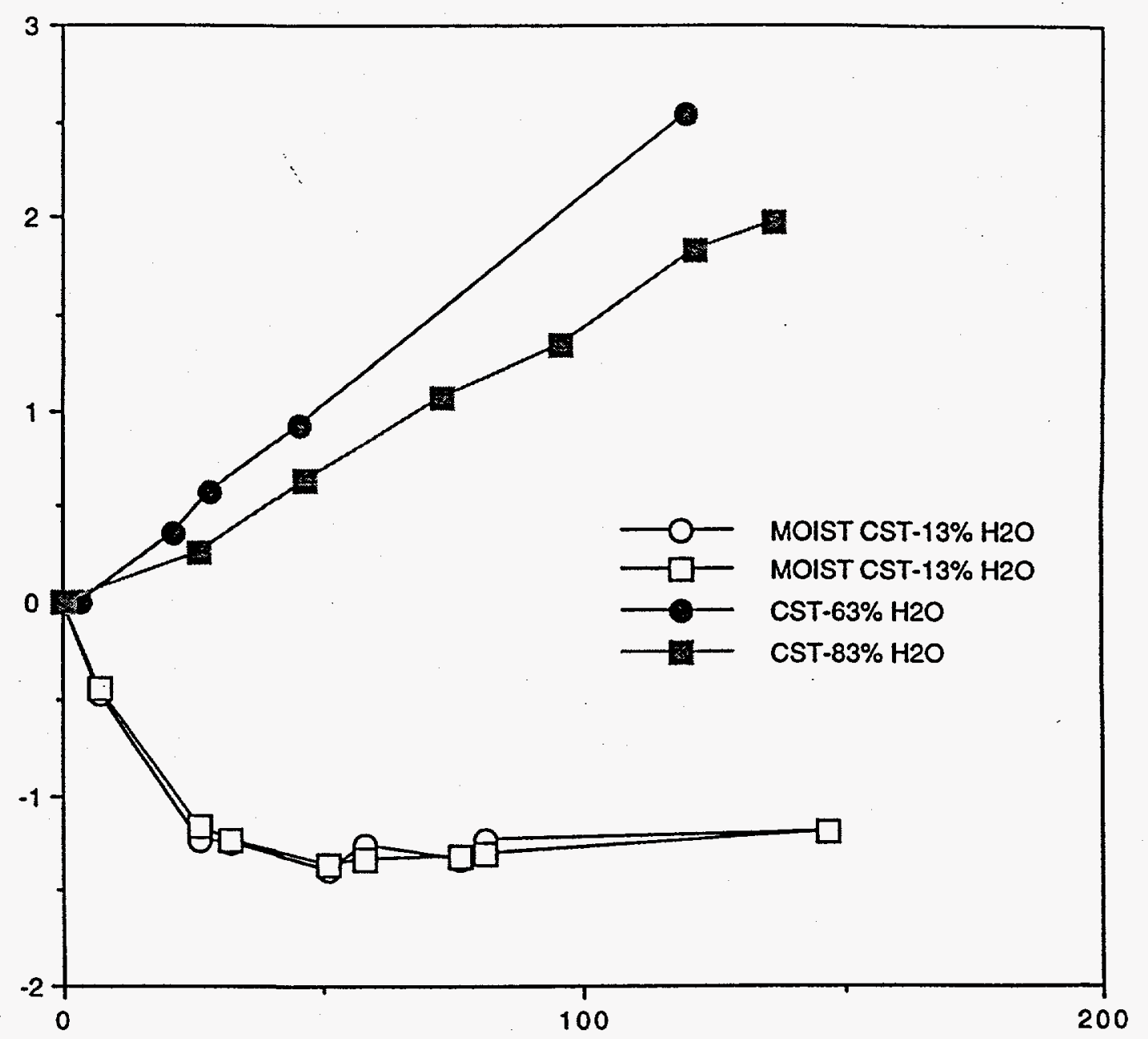

IRRADIATION TIME (HOURS)

Figure 3. Pressure Changes Produced from Irradiation of CST and CST-Water Slurries 
For the as received moist CST the pressure decreased initially and then gradually increased after about 50 hours of irradiation. The final pressure of these systems remained below atmospheric pressure. This CST appeared dry and was an easily flowing powder. This type of radiolytic induced pressure decrease has been observed previously when as received zeolites were irradiated (8) or organic resins are irradiated (9). This pressure decrease is most likely due to $\mathrm{O}_{2}$ depletion in the air initially sealed in the system. Trapped electrons are formed in the CST by the radiation and these electrons can easily react with $\mathrm{O}_{2}$ to produce oxide species. Depletion of $\mathrm{O}_{2}$ causes a pressure decrease. The fact that this depletion eventually ceases may indicate that this $\mathrm{O}_{2}$ reaction occurs primarily on the surface of the particles.

A test was performed to determine if the observed pressure decreases were indeed due to radiolysis or if the CST in the sealed system was just absorbing water vapor and decreasing the pressure. To do this test, moist CST was sealed in the system and it was allowed to sit in the absence or radiation for several days. There was no indication of gas depletion and the sealed system pressure remained at $14.4 \pm 0.2$ PSIA over approximately nine days of testing.

As shown in Table 2, the $\mathrm{G}$ value for $\mathrm{H}_{2}$ based on energy absorbed by the total system is very small. However, when based on the energy absorbed by the water only the value is increased in proportion to the mass fraction of the water present. This value of 0.14 molecules $/ 100 \mathrm{eV}$ is smaller than 0.45 (the value for pure water (7)) indicating that CST is not transferring energy to the water and enhancing $\mathrm{H}_{2}$ production. If energy transfer were occurring, the $\mathrm{G}$ value based on energy absorbed by the water would be larger than 0.45 molecules $/ 100 \mathrm{eV}$.

The $63 \%$ water slurry resembled damp CST and was intended to simulate the CST slurry in a processing column through which supernate would be passed to remove Cs-137. For this system, the pressure increased linearly within experimental error with time or radiation dose. The $\mathrm{G}$ value for $\mathrm{H}_{2}$ for the $63 \%$ water slurry was 0.20 molecules $/ 100 \mathrm{eV}$ based on energy absorbed by the entire system and 0.32 based on the energy absorbed by the water. The value based on energy absorbed by the water is still lower than 0.45 - again indicating that energy absorbed by the CST is not transferred to the water and causing it to decompose to give $\mathrm{H}_{2}$.

The $83 \%$ water slurry could easily be poured and was intended to simulate a CST slurry that could be pumped or a slurry that might be stored in a tank until transfer to the DWPF. As shown in Figure 3, the pressure increased linearly within experimental error as with the $63 \%$ slurry. The $\mathrm{G}$ value for $\mathrm{H}_{2}$ based on energy absorbed by the water is 0.18 molecules $/ 100 \mathrm{eV}$ which is lower than 0.45 indicating that energy absorbed by the CST is not transferred to the water to make $\mathrm{H}_{2}$. 
The $\mathrm{G}$ value for $\mathrm{H}_{2}$ based on energy absorbed by the both the CST and the water is 0.15 which is lower than the value found for the $63 \%$ water system. This is consistent with the fact that in this system there is more free water or water that is not associated with the CST. In fact, in this system the CST settles and there is definitely clear water above the CST. This was undoubtedly the configuration during most of the time that the system was being irradiated. In this water during radiolysis, dissolved $\mathrm{H}_{2}$ could react with the $\mathrm{OH}$ radials being produced by the radiation and thus decrease the amount of $\mathrm{H}_{2}$ being released from the solution to cause a pressure increase. In fact, when pure water is irradiated there is no pressure increase due to back reactions in the water to reoxidize the $\mathrm{H}_{2}(7)$. The mechanism for this has been well documented in the literature of radiation chemistry $(7,10)$.

\section{Irradiation of a CST/1M NaOH Slurry}

Based on the radiation chemistry of water it is expected the $\mathrm{G}$ value for $\mathrm{H}_{2}$ production is not dependent on $\mathrm{pH}(7,10)$. A test was performed with $37 \% \mathrm{CST} / 63 \% 1 \mathrm{M} \mathrm{NaOH}$ slurry. In this test the $\mathrm{G}$ value for $\mathrm{H}_{2}$ based on energy absorbed by the entire slurry was 0.24 molecules $/ 100 \mathrm{eV}$ in agreement with that determined with CST/63\% water. Based on energy absorbed by the $1 \mathrm{M}$ $\mathrm{NaOH}$, the $\mathrm{G}$ value was 0.35 in agreement with that determined for the CST/63\% water slurry based on the energy was absorbed by the water. As expected, the $\mathrm{pH}$ of the solution did not affect the radiolytic production of $\mathrm{H}_{2}$.

\section{Irradiation of a CST/NO3 ${ }^{-} \mathrm{NO}_{2}^{-}$Salt Solution/ Slurry}

To determine the effect of nitrate and nitrite in the salt solution on $\mathrm{H}_{2}$ production, a $61 \% \mathrm{CST} /$ $39 \%$ salt solution slurry was irradiated. Previous studies have shown that these two ions in solution decrease the $\mathrm{G}$ values for $\mathrm{H}_{2}$ production $(7,10)$. The salt solution was $5.6 \mathrm{M} \mathrm{Na}^{+}, 2.1 \mathrm{M}$ $\mathrm{NO}_{3}^{-}, 0.5 \mathrm{M} \mathrm{NO}_{2}^{-}$and $1.9 \mathrm{M} \mathrm{OH}$. This $39 \%$ slurry was to simulate the packed CST slurry that would be in a column as the salt solution was passing through it to remove the Cs-137. Based on energy absorbed by the total system during a 136 hour irradiation and the final $\mathrm{H}_{2}$ concentration in the gas, the $\mathrm{G}$ value for $\mathrm{H}_{2}$ production was 0.05 molecules $/ 100 \mathrm{eV}$. This is $4 \mathrm{X}$ lower than the $\mathrm{G}$ value for $\mathrm{H}_{2}$ production from the CST/63\% water system and CST/63\% NaOH system. 


\section{RESULTS OF CALCULATIONS TO ESTIMATE $\mathrm{H}_{2}$ PRODUCTION FROM A PROCESS} COLUMN CONTAINING Cs-137 AND CST

The following calculations were performed assuming that the Cs- 137 concentration on the CST was one weight percent and using the maximum $\mathrm{G}$ value of 0.2 molecules $/ 100 \mathrm{eV}$ determined in this study for energy absorbed by the CST slurry. One weight percent is probably the maximum loading of Cs-137 on the resin (11). .

\section{Radioactivity Loading per Gram of Fully Loaded CST}

Cs-137 has a specific activity of $87 \mathrm{Ci} / \mathrm{g}$ (12). With a loading is one gram of Cs-137 per 100 grams of CST; thus, the Cs- 137 Curie loading of the resin is 0.87 Curies per gram of resin. The Cs-137 decays to $\mathrm{Ba}-137 \mathrm{~m}$ and to stable Ba-137. Ninety five percent of the Cs-137 decays to radioactive $\mathrm{Ba}-137 \mathrm{~m}$ (12) which has a very short half life compared to that of Cs-137. Ba-137m decays to stable $\mathrm{Ba}-137$. Thus the $\mathrm{Cs}-137$ is in secular equilibrium with its radioactive daughter Ba- $137 \mathrm{~m}$. This means that there are 0.95 Curies of Ba- $137 \mathrm{~m}$ for each Curie of Cs- 137 . The total Curie loading to the resin is then 1.7 Curies/g. Cs-137 is a beta emitter and decays emitting a total of 1.01 watts per $1000 \mathrm{Ci}(12) . \mathrm{Ba}-137 \mathrm{~m}$ is a gamma emitter and the decay energy is 3.94 watts per $1000 \mathrm{Ci}(12)$. The beta heat load per gram of resin is then, $8.8 \mathrm{E}-04$ watts. If all the gamma energy is absorbed, the gamma heat loading is 3.3E-03 watts per gram of resin.

(Obviously not all the gamma energy is absorbed in a gram of resin, but in a processing column or tank it probably is due to the large size of the vessel.) In this case the total heat loading is 4.1E-03 watts per gram of resin.

\section{Radioactivity Loading per Processing Column of CST}

For this calculation it was assumed that a processing column was 16 feet long and 5 feet in diameter (11). With these dimensions and a density of $1 \mathrm{Kg}$ of CST per liter of resin bed (13), the processing column contains $8.9 \mathrm{E}+06$ grams of resin. The total Curies on the resin including those of Cs-137 and Ba- $137 \mathrm{~m}$, is $1.5 \mathrm{E}+07$ Curies. With a column this size it can be shown that greater than $95 \%$ of all the gamma energy is absorbed; thus, the total wattage in the column is 37 kilowatts. 


\section{$\underline{\text { Rate of Radiolytic } \mathrm{H}_{2}} \underline{\text { Production per Gram of Fully Loaded CST }}$}

The rate of $\mathrm{H}_{2}$ production can be calculated using a $\mathrm{G}$ value of $\mathrm{H}_{2}$ production of 0.2 molecules per $100 \mathrm{eV}$ of energy absorbed. The necessary conversion factors are, $1 \mathrm{eV} / \mathrm{sec}$ equals $1.6 \mathrm{E}-19$ watts and one mole ( $6.0 \mathrm{E}+23$ molecules) of $\mathrm{H}_{2}$ occupies $22.4 \mathrm{~L}$ at STP. If the loading is $4.2 \mathrm{E}-03$ watts per gram of resin, then 1.1E-07 liters(STP) of $\mathrm{H}_{2}$ will be produced per minute.

\section{$\underline{\text { Rate of } \mathrm{H}_{2} \text { Production per Processing Column of CST }}$}

The processing column contains $8.9 \mathrm{E}+06$ grams of resin, thus $\mathrm{H}_{2}$ will be produced at a rate of one liter per min or 0.04 standard cubic feet per minute. Presuming that this $\mathrm{H}_{2}$ diffuses out of the column to the head space above it, the purge rate to ensure that the concentration of $\mathrm{H}_{2}$ remains below the flammability limit for $\mathrm{H}_{2}$ would have to be $1 \mathrm{scfm}$.

\section{REFERENCES}

1. M. Nakashima and Y. Aratono, "Radiolytic Hydrogen Gas Formation from Water Absorbed on Type A Zeolites," Radiat. Phys. Chem. Vol. 41, 461-465 (1993).

2. N. E. Bibler and C. L. Crawford, "Test Plan for Determining Radiolytic Hydrogen Production from Moist CST," SRT-VTB-98-018, July 30, 1998.

3. D. D. Walker, W. D. King, D. P. Diprete, L. L. Tovo, D. T. Hobbs and W. L. Wilmarth, "Cesium Removal from Simulated SRS High-Level Waste Using Crystalline Silicotitanate," WSRC-TR-98-00344, Rev. 0, October 2, 1998.

4. T. L. Fellinger, Private Communication, October, 1998.

5. E. Hart and S. Gordon, "Gas Evolution for Dosimetry of High Gamma, Neutron Fluxes," Nucleonics, 12, 40-43 (1954).

6. N. E. Bibler, "Calibration of Intense Co-60 Gamma Ray Souces at the Savannah River Plant,” Report DP-1414, Savannah River Laboratory, Aiken, SC, May 1976. 
7. I. G. Draganic and Z. D. Draganic, "The Radiation Chemistry of Water," Academic Press, NY (1971).

8. N. Bibler, R. Wallace, and M. Ebra, "Effects of High Radiation Doses on Linde Ion Siv IE-95," DP-MS-81-18, (1991).

9. C. L. Crawford and N. E. Bibler, "Radiolytic Hydrogen Production During the Long Term Storage of Spent Organic Ion Exchange Resins," Proceedings of Waste Management '95, CD-ROM, Edited by R. G. Post, 1995.

10. A. O. Allen, "The Radiation Chemistry of Water and Aqueous Solutions," D. Van Nostrand Co., Inc., Princeton, New Jersey, p.62, 1961.

11. J. R. Harbour, Private Communication, October, 1998.

12. "Integrated Data Base Report-1994: U.S. Spent Fuel and Radioactive Waste Inventories, Projections, and Characteristics," DOE/RW-0006, Rev. 11, September, 1995.

13. D. D. Walker, Private Communication, October, 1998. 